\title{
Jade Myths and the Formation of Chinese Identity
}

\author{
YE Shu-xian \\ Shanghai Jiaotong University, Shanghai, China
}

\author{
LIU Wan-er \\ Beijing Institute of Technology, Beijing, China
}

Reality is constructed by societies, whose process must be analyzed by the sociology of knowledge. The "reality", taken as granted by the public, has sharp contrast from one society to another.

By Peter Berger and Thomas Luckman: The Social Construction of Reality

Chinese civilization is the only surviving one that has a continual history that lasts for several thousand years since the Stone Age. What's the secret of its lasting cultural vitality? How can it live through numerous military conflicts and political transitions and still firmly hold a large population of various ethnics within its administration? A long-established cultural centripetal force, i.e. cultural identity shared by multi parties, shall be the key to former questions. According to current focus of cultural research, this force is termed as "Chinese identity", which explores the formation and continuation of Chinese civilization from the perspective of cultural identity. What is cultural identity? A simplified answer is:

Cultural identity fundamentally refers to ethnicity. This characterizes a group whose members claim a common history or origin and a specific cultural heritage, no matter that the history or origin is often mythicized or that the cultural legacy is never totally homogeneous. The essential thing is that these common elements are lived by the concerned group as distinctive characteristics and perceived as such by others ${ }^{1}$.

Though neglecting many facets (such as the linguistic, economic, religious, or conventional ones) contained in cultural identity and simply equalizing cultural identity to ethnicity, this interpretation by Selim Abou has grasped the core element of identity — certain mythicized history or shared cultural heritage. When the mythicized cultural heritage is shared by a larger group that has many ethnics, cultural identity should be interpreted on a higher level, from "ethnicity" to "nationality”. This paper, seeing from the angle of "nationality", explores the formation of Chinese identity through a critical cultural heritage -jade myths, explains the centripetal force that promoters the prehistoric multi-cultures to the integrated civilization of Central Plains, and interprets the structure between the multi-cultures and the integral one and formation of Chinese culture.

Max Weber is one of the founders of modern sociology who inherited Dilthey's "moral science" and Rickert's "cultural science". He believed that social science research can develop a "cultural science" which, unlike the natural science that explores the universal rules of things, explores the values of specific culture and

YE Shu-xian, Chair Professor, Shanghai Jiaotong University, China. Director and Professor of Comparative Literature, Chinese Academy of Social Sciences. Editor in Chief of “The Series of Anthropological Explanation of Chinese Classics". His research field covers Chinese Literary Anthropology, Cross-culture Research, Chinese Classical Culture and Comparative Literature.

LIU Wan-er, Graduate of Beijing Institute of Technology, China.

1 Abou, Selim. The Metamorphoses of Cultural Identity. Tans. Xiao Junming. Ed. The Editing Committee of Diogenes' Chinese Special Version. Beijing: The Commercial Press, 2008. P. 11. 
the cultural phenomena or the "meaning" of social reality dominated by these values. In 1904, Weber pointed in his thesis that:

All knowledge of cultural reality, as may be seen, is always knowledge from particular points of view. When we require from the historian and social research worker as an elementary presumption that they distinguish the important from the trivial and that he should have the necessary "point of view" for this distinction, we mean that they must understand how to relate the events of the real world consciously or unconsciously to universal 'cultural values' and to select out those relationships which are significant for us. ${ }^{2}$

Since the cultural phenomena are complex, most researchers have difficulty in distinguishing the important from the trivial. Many of them are still stuck in the trivial and ignore the underlying values hidden behind the culture. Some may be conscious of these values, but they are unable to grasp the most central values of certain cultural system, since they lack the capacity to penetrate through the dense fog of cultural phenomena. Weber's suggestion can direct our research practices. This paper, starting from the long-ignored cultural phenomena - Chinese jade myths, hopes to explore the origin of those core values that have accompanied the formation of Chinese civilization and explain how they function as the spiritual bonding in the formation of Chinese identity.

\section{Introduction: From the “Golden Bough" to the “Jade Leaf”}

At the turn of 19th and 20th century, an anthropological works, which has been far more influential than what the author and publisher expected, appeared. It influenced most famous poets and novelists of the 20th century, including T. S. Eliot and James Joyce. It is The Golden Bough ${ }^{3}$ by J. G. Frazer. A question occurred to me that why a 12-volume book on the religions of the world's old cultures and the west was named as "golden bough"? Since boughs made from gold do not exist in reality, how literary imagination has connected the metal and the plant?

In the first edition of The Golden Bough, Chapter One of Volume one referred to the story that Diana, the Goddess of Nemi Lake, was worshiped as “the King of the Wood”. Within Diana's temple grew a special tree, protected by the priest, no branch of which might be broken. Only a runaway slave was allowed to break off, if he could, one of its boughs. Success in the attempt entitled him to fight the priest in single combat, and if he slew him he reigned in his stead with the title of King of the Wood (Rex Nemorensis). According to the public opinion of the ancients the fateful branch was the Golden Bough which, at Sibyl's bidding, Aeneas plucked before he essayed the perilous journey to the world of dead. ${ }^{4}$

The golden bough, as a mysterious magic weapon, originally belonged to the goddess of the world of the dead, not to the secular world. Mythological imagination gives the plucked bough the capacity to independently grow, which implies the magic rebirth power of life. Immortality is the basic theme of all prehistoric mythological belief systems, which is inherited in the form of literature and combined with the metal myths since the Bronze Age. ${ }^{5}$ As a rare metal massively mined with the coming of civilization, gold became a sign of

\footnotetext{
${ }^{2}$ Weber, Max. The Methodology of the Social Sciences. Trans. And Ed. A. Shills, Edward. A. Finch, Henry. Illinois: The Free Press of Glencoe, 1949. P. 81.

${ }^{3}$ Frazer, J. G. Translated by Xu Yuxin et al. Beijing: Press of Chinese Folk Literature and Art, 1987.

${ }^{4}$ Frazer, J. G. The Golden Bough .Vol. 1. London: Macmillan, 1955. P. 11.

${ }^{5}$ Frazer, J. G. The Belief of Immortality and the Worship of the Dead. London: Macmillan, 1922. Pp. 3-22.
} 
holiness and immortality. Alchemy, which integrated the hope of immortality in prehistoric myths and the desire for gold in civilized society, became an active and continuous practice. Plants in reality have their birth and death, and their lives are not characterized with the annual circulation of flourishing and decaying. However, the golden bough and leaf in Roman mythology goes beyond the boundary of birth and death, becoming the magic light that directs and light up the way of the world of the dead.

Focus on the necessary connection between gold and godhood in Roman mythology is the key to understand this story. At the beginning of Book VI of the Aeneid, Diana's temple is referred to as "being roofed with gold"6 Zeus, the the supreme god of the ancient Greeks, once turned into the gold rain to date the princess Danae. In The Theogony, Hesiod referred Hera, the Queen of Heaven, as "the goddess in golden shoes", and when referring to other gods, he also used "Hebe who wears gold crown”, "Pheobe in gold crown” etc. ${ }^{7}$ At first, gold was holy material that belonged to the deities. Under Virgil's pen, the golden bough grew on a tree with golden leaves, which, besides showing a golden color, gave away a clanking sound. The semi-god hero found this treasure under the guidance of a pair of doves. This detail shows that the golden bough was the holy gift from the deities, which was beyond ordinary people's reach. Since dove, in Christian myths, is the symbol of the Holy Spirit. ${ }^{8}$ According to New Testament, in Gospel of Saint John, John testified that "I saw the Holy Spirit, coming down from the heaven like a dove, and resting on Him." "In western mythological belief, dove is the medium connecting man and god, which is obvious in this story. Analysis on the stories relating Roman ancestors and holy articles can lead us to a narrative mode dominated by mythological concepts: certain king or hero, under the direction of a medium that conveyed god's will, obtained certain symbolic holy article (treasure), by which he accomplished causes that couldn't be achieved by ordinary people.

The theme of magic treasure, whether it is the golden apple, the Golden Fleece, Aladdin's lamp, or the calabash containing secrets, even the magic stone, the tree satisfying wishes or the magic ring, is essential to all nations' narrative literature. Even in China, since the medieval times, pictures narrating that the Northern tribes contributed treasures to the emperor have been common in jade carvings, which entrusted the foreign tribes with the task of bringing rare treasures.

Magic treasures also appeared in Chinese mythological narrations relating to the ancient heroes or kings. What's different is that the material for Chinese treasures is jade, not gold. This results from the several-thousand-year "Jade Age" experienced by Chinese civilization during its formation. Gold has had a history of around 3,000 to 4,000 years ${ }^{10}$, while jade of around 7,000 to 8,000 years ${ }^{11}$, which is twice that of gold. I'd like to adopt anthropological terms - "little tradition” to call the cultural tradition marked by metal and Chinese characters, and "great tradition" to call the cultural tradition before the appearance of characters, metals

\footnotetext{
${ }^{6}$ Virgil. Aeneid. Translated by Rorbert Fitzgerald. New York: Vintage Books, 1983. P. 159.

7 Hesiod. The Works and Days: The Theogony. Tran. Zhang, Mingzhu. Beijing: The Commercial Press, 1991. Pp. 27, 30.

${ }_{9}^{8}$ Gaskell, G. S. Dictionary of Scripture and Myth. New York: Dorset Press, 1989. Pp. 229-230.

9 New Testament: Gospel of Saint John. Chapter One, Articles 32-33.

${ }^{10} \mathrm{Li}$, Jinghua. Archeology of Metal Smelting. Beijing: Press of Cultural Relics, 2007. P. 26. Li thinks that Chinese metallurgy of gold and silver started from the transition period of Shang and Zhou dynasties.

${ }^{11}$ Exploration of the Origin of Jadeware. Edit. Archeological Institute of Chinese Academy of Social Sciences (CASS) and Chinese Archeology Center of Chinese University of Hong Kong (CUHK). Hong Kong: Chinese Archeology Center of Chinese University of Hong Kong, 2007. P. 232.
} 
and nations. ${ }^{12}$ Through re-exploration of the great tradition, I hope to re-interpret the cultural genes and cultural encoding of the little tradition, and eventually understand the origin and characteristics of the formation of Chinese nationality.

The following is examples of the mythological narrations which can help us interpret the characters of little tradition through the knowledge of great tradition. The first example comes from The Classic of Mountains and Seas - the Yellow Emperor planted "jade flowers", which can be seen as a typical case of China's "jade bough and jade leaf":

Dan River came out of the Cen Mountain, and went west into the Cheng Pool. In the river grew many white jades. So did some jade cream whose origin was boiling. The Yellow Emperor fed on this cream. Thus produced black jades. Watered by jade cream for 5 years, the Dan plant became colorless and smelt sweet. So the Yellow Emperor took jade flowers from the mountains and planted them on the southern side of the Zhong Mountain (Guo Pu annotated: "This is the so-called jade seeds”). Beautiful jades were pretty good, solid and exquisite. With gentle lustre, they shone lights and seemed soft. Since the ghosts and gods fed on jades, by wear them, gentlemen could be protected from ominous things. $^{13}$

The above jade myth seems magnificent and magical. With relation to the ancestor of Chinese civilization — the Yellow Emperor, it contains the core values of Chinese civilization that's worthy of further exploration. The explanation of Guo Pu et al. clarifies the core idea of this passage: in the San Mount. which was located in the west part of China, to the north-west of Buzhou Mount., there was a river named Dan River, which went west into Cheng Pool; Dan River did not only produce white jades, but also nourished jade creams that poured out like springs; and from the jade cream was born black jades; with the irrigation of the jade cream, a kind of jade trees, named Dan Tree, grew; at the 5th year of the trees, they showed five colors and gave away five fragrances. The Yellow Emperor was the hero of this jade myth: firstly, he enjoyed the jade cream as a delicacy, the planted jade trees: he used the jade follower produced by the jade of the San Mount. as jade seeds, and planted them on the south side of Zhong Mount. Thus produced the best jade materials which was called "Jin Yu Jade" (beautiful jade) ${ }^{14}$. Such jades were characterized of being hard, dense and heavy, giving out gentle lustre and appearing colorful like the original Dan Tree. Such characteristics and appearance of Jin Yu jades fully display the concept of jade virtues illustrated by Confucius, the connoted value of "overcoming the hard with the gentle" and the traditional custom of "a gentleman must wear jades" etc. The "Jin Yu jade” planted by the Yellow Emperor has the same magic as the "golden bough" in the western myths. The Classic of Mountains and Seas briefly refers to its two functions: first, being the delicacy enjoyed by the gods and ghosts to increase their supernatural powers; second, being worn by gentlemen to protect them from the evil and unlucky things. These two functions of Chinese jades make them the bridge connecting man and god. This is meaningful since it exactly

\footnotetext{
12 Ye, Shuxian. Exploring the Great Tradition of Chinese Culture. Social Scientists, 2011 (11).

${ }^{13}$ Yuan, Ke. Collation and Annotation to The Classic of Mountains and Seas. Shanghai: Shanghai Publishing House of Classics, 1980. P. 41.

${ }_{14}$ According to Zuo Zhuan: Xuan 15., "a saying goes that 'your status is determined by how tolerant your heart is, like rivers and ponds that accept wastes, like mountain lakes that hide sickness and like the beautiful jade that conceal flaws'”. According to the statement of Kong Yingda, "Jin Yu, the beauty of jades". According to Beautiful Jades That Hide Conceal Flaws written by Ouyang Zhan of Tang Dynasty: "the beauty of jade is called Jin Yu". In The Song of Chu: Nine Pieces-Embracing Sand: "holding Jin Yu, I feel confused and have no idea of where to go". In The Classic of Mountains and Seas: Classic of the Mountains: West: “to worship the god of mountains...one hundred Yu was needed”. According to Guo Pu's illustration: "Yu, the name of beautiful jades”.
} 
combines the origin of Chinese jade worship and jade culture with the holy behavior their national ancestor, the Yellow Emperor, which can be seen the "Genesis" of Chinese civilization in the national memory.

Therefore, jades explicitly become the secular bonds between man and god and the holy media to realize "the integrity of man and god". Certainly, jades also turn to be the literary theme of many poets and writer through the ages. Many works surround similar holy articles to construct their space of imagination and fantasy. Let us first see the recreation of "jade cream”. In Guo Pu's illustration, he quoted from The Map of Rivers: “on the Shaoshi Mountain, there is white jade cream. Once “fu” (服) the cream, man will become an immortal”. The Chinese “fu” (服) can mean two actions: “to eat (food)” and “to wear (clothes, jewelries etc.)”. Here, it’s more proper to be interpreted as "to eat". No matter man eat or wear the jade cream, man got the magic of becoming an immortal. In Song to the South Capital, Zhang Heng of the Han Dynasty said: "ganoderma lucidum grew in the houses, and jade cream filled all corners of the houses". Here, jade cream is put together with another magic medicine in Chinese medical myths — ganoderma lucidum. In the first volume of Encyclopedia of Nature, Zhang Hua of the Jin Dynasty said: "among the famous mountains and rivers, inside the holes and caves, natural Qi interacts and consequently gives birth to stone juice and jade cream. Eating them, man will not die.” In his fourth poem of Reading The Classic of Mountains and Sea, Tao Yuanming said that "Where the Dan Tree grows? On the south of Mi Mountain. Yellow flowers and red seeds. Eating them, life expands. White jade produces juices, beautiful jades shine magic lights. Aren't they gentlemen's treasure? So much treasured by our Yellow Emperor”. ${ }^{15}$

Tao did not only love singing the story of Yellow Emperor's eating jade cream, but also imagined the jade cream as the juices from white jades, which inspires the later generation fantasy about jade juices. ${ }^{16}$ The previous writers, relating to Yellow Emperor's jades, were leading the observation of nature things to the core concept of immortality. They were more of the inheritance from the prehistoric jade myths, than the creation of ancient men of letters. Seen from the description of "beautiful jades shine magic lights", the difference between the west and east mythologies — gold worship and jade worship—results from the difference of the lightening minerals. The lustre and color of gold obsessed the Greek and Roman writers ${ }^{17}$, in the same way beautiful jades, jade cream and jade flowers obsessed those Chinese writers.

The Classic of Mountains and Seas described the geographic scope where the Yellow Emperor planted the jade flowers: he got the jade seeds from San Mount. and planted them to the south side of Zhong Mount. "It was 460 li (230 km) from San Mount. to Zhong Mount.” How did Yellow Emperor cover such a distance? We can’t know. We also have no idea about how the local white jade cream of San Mount. gave birth to black jades, which seemed to be mysterious and magical. The white and black colors and their interaction make us think of the Taiji Tu. Jade myths break the limitations of things which cannot happen in the real world and build an integrated magical world. Penetrating the complicated and confusing appearances, we can grasp the basic concepts of jade myths: jade represents god, represents magical changes, and represents immortal lives. These three connotations are enough to construct the core values of a culture.

\footnotetext{
${ }^{15}$ Works of Tao Yuanming. Annotated by Dai Qinli. Beijing: Zhonghua Book Company, 1979. P. 135.

${ }^{16}$ According to Bibliographies of Immortals: “Chisong Tzu, the rain god of the Shennong era. He ate jade juices and couldn’t be burnt when he was in fire. He taught this to Shennong”. In Records of Ten States: "Ying State has jade cream like wine, name jade wine. Drinking several litres, man won't die”.

${ }_{17}$ Bernstein, Peter L. The Power of Gold: The History of an Obsession. Trans. Huang, Lei. Shanghai: Shanghai University of Finance and Economics, 2008. Pp. 1-6.
} 
In the Period of Warring states when The Classic of Mountains and Seas was written, gold had finished its millennium journey from the Western Regions to the Central Plains' civilization. ${ }^{18}$ The most common narrative mode of this book is the resource reports of the mountain and rivers which emphasizes both the gold and jade. For example, in Classic of the Mountains: West, Zou Mount. is recorded as "there are no grass or trees on it. Qi River comes out of it and goes west into the sea. In the river, there are many colorful stones, gold and cinnabars”. ${ }^{19}$ Shuli Mount.: "on the mountain, there is much gold. At its foot, there is much silver. Most of its trees are large and stark and most birds are parrots. Chu Rivus comes out of it and goes west into Wei River. In the river, there are many white jade balls." ${ }^{20}$ Longshou Mount.: "on the south side of the mountain is much gold and the north side iron. Tai Rivus comes out of it and goes southeast to Jing River. In the river, there are many beautiful jades”. ${ }^{21}$ Zhongshou Mount.: "many jades dispersedly float on it. At its foot are many wingceltis and tangerines and gold. Most of its beasts have sharp horns." ${ }^{22}$ In such report mode which emphasize both metal and jade or stone resources, all gold, silver, bronze and iron are included, which have great economic values to human life. But none of them can compete with jade in the way it is closely connected to the ancestor of Chinese civilization and turns into magic articles.

Up to now, we have traveled through the western "golden bough" to the eastern "jade leaf". If someone wants to ask: is people's ideal "tree of life" as green and gentle as the jades or as shining and glimmering as gold? Obviously, different cultural views will give us different answers. All the cultural values contained in jade myths have been shown through the former comparative studies and analysis. If we take into consideration many Chinese idioms, like "rather die for jade than live for tiles" or "change shields and daggers to jade objects and silk fabrics", we will know more clearly the values and meanings of jade myths in the deep spirits of Chinese.

\section{Jade as Treasure: The Mythological History of Xia, Shang and Zhou}

\section{The Myth of Xia Yu's Tampering Rivers With the Help of Jade He Gained}

The second jade myth to be analyzed comes from Shang Shu and Records of the Grand Historian, which is a historical myth telling about Yu the Great, who was the first outstanding statesman who founded the nation by taming the rivers. In the Yao and Shun ages, there are historical records of "collecting 5 jades" and "issuing the jades to tribal leaders", where jades were regarded as sacrificial articles symbolizing the national power. ${ }^{23}$ In ancient China, all generations of the early countries worshiped jades as holy treasures. Take Xia dynasty as an example, "seen from the documents, the success or failure of the kings of Xia dynasty is determined by whether they owned jades. The ownership of jades was of great importance to the rulers of Xia, as great as the importance

\footnotetext{
18 To know the special relations between the origin of Chinese mining and the Hexi Corridor, please see: Part 3 of Chapter 7 of Hexi Corridor: Western Myths and the Origins of Chinese Civilization. Written by Ye, Shuxian. Yunnan: Yunnan Education Press, 2009.

19 Yuan, Ke. Collation and Annotation to The Classic of Mountains and Seas. Shanghai: Shanghai Classics Publishing House, 1980. P. 32.

${ }^{20}$ Yuan, Ke. Collation and Annotation to The Classic of Mountains and Seas. Shanghai: Shanghai Classics Publishing House, 1980. P. 34.

${ }^{21}$ Yuan, Ke. Collation and Annotation to The Classic of Mountains and Seas. Shanghai: Shanghai Classics Publishing House, 1980. P. 35.

${ }^{22}$ Yuan, Ke. Collation and Annotation to The Classic of Mountains and Seas. Shanghai: Shanghai Classics Publishing House, 1980. P. 37.

${ }^{23}$ Ye, Shuxian. Shun Issued Jades to Tribe Leaders After the Abdication From Yao: The Myth History of the Two Legendary Rulers. Nanning: Ethnic Arts Quarterly, 2012(1).
} 
of Iraq's oil to the Bush president of USA. According to Shang Shu: Tribute of Yu, 'Yu gained black jade and successfully became the king. ${ }^{24}$ In Records of the Grand Historian: Annals of Xia, 'the Jade Emperor (supreme ruler of Heaven in Taoism) gave Yu black jade to show the world that Yu had became the King.' Seen from this, we can say that Yu the Great depended black jade — a mysterious sacrificial jade article — to become the king of people. In The Mo Zi: No Attack II, 'Yu, holding the black jade given by the Jade Emperor, went to conqueror the Youmiao tribe.' Black jade was the jade token from the heaven. In such an era that all rites, music and wars were started by the son of heaven, anyone who had the holy jade from the heaven had the right to rule the world."25 Later, some adaptations of Yu's story appeared: what Yu got was jade slip or jade letter, or it was from Fuxi Emperor that Yu got the jade latter. Wang Jia of the Jin dynasty wrote in his Anecdotes of History: Yu of Xia: “another god appeared, with man's face and snake body. Yu talked to him. Then the god showed the Bagua to Yu... he gave Yu the jade letter, which was 12 cun $(0.4 \mathrm{~m})$ long. It matched the 12 number, so that it could measure the sky and land. Yu, holding this jade letter, conquered the waters and soils. The god, with man's face and snake's body, is Fuxi Emperor." Such adaptation, appearing in later age, still conformed to the narrative mode of hero myth and epic ages: the hero, under the guidance of heaven's messenger, gained a holy treasure; and with the help of this holy treasure, the hero accomplished a cause which couldn't be accomplished by the ordinary people. Just as Aeneas who gained the golden bough with the guidance of the prophet and the dove, Yu of Xia gained the jade letter under the guidance of Fuxi Emperor.

Zhao Hua of Han dynasty had another version about Yu’s jade story. In his History of Wu and Yue States: Anecdotes of King of Yue - Wu Xu: "in winter, Yu climbed the Yuanwei Mountain. There he discovered a gold book with jade characters, in which he learned the way to tame waters.” In this paper, jade article was replaced by the book combing both gold and jade, which was obviously the imagination of people on that day. Since at the beginning of Xia dynasty, there was no gold or characters, the imagination didn't fit the reality, but it matched the concept of "the music of gold and jade" treasure which appeared after the Warring States period, which was more inspiring to the man of letters. For example, in Tablet Inscription for Gold Hall On the Tongbai Mountain written by Shen Yue of the Liang dynasty, "writings on gold slips with jade characters were treasure as precious as the black frost and crimson snow, which couldn't be looked at by the ordinary people or overlooked by the intellectuals." The lustre of gold and jade, glittering together, contributed to the imaginative scenery of "Jin Bi Hui Huang (金碧辉煌)” (which means, looking splendid in green and gold, just like gold and jade vied with each other). According to The Book of the Later Han: Zhang Heng's Bibliography, “during the Yongyuan Years (the reign tile of Liu Zhao, Emperor He of Han), Song Jing of Qinghe County predicated the flood by the referring to the historical records, but pretended to claim that he had peaked at the jade writing”. In his annotation to Dunjia Kaishan Tu (《遁甲开山图》), Li Xian said: “Yu the Great traveled to the Eat Sea, gained the jade letter which was green in color, 40 centimeters long and as round as the sun or moon. Looking at with naked eyes, people would enter the spiritual world. ${ }^{26}$ Thus, Chinese literature memorizes Yu the Great, the founder of the first dynasty, through a mysterious jade treasure, which Chinese intellectuals took delight in talking about and repeatedly

\footnotetext{
${ }^{24}$ Shang Shu: Tribute of Yu. One of the serial books-Annotated 13 Classics. Beijing: Zhonghua Book Company, 1980. P. 153.

25 Ye, Shuxian. The Jade Narrattives and the Mythological History of Xia Dynasty. Chinese Social Sciences Today. July 1st, 2009.

${ }^{26}$ Wang, Xianqian. Annotation to The Book of Later Han. HongKong: Chung Hwa Book Co., 1984. P. 668.
} 
praised. This forms a mutual reflection with the story of Roman ancestor, Aeneis and his golden bough.

\section{The Myth of Xia Qi’s Entering Heaven by Gaining a Semi-Circular Jade}

The third jade myth is about Qi of Xia, who entered the heaven by gaining a semi-circular jade. As the son of Yu the Great, Qi was the creator of imperial family, i.e. the first who inherited the throne from his father. He also regarded the jade ware as the symbolism of supreme royalty. The difference was, the holy jade ware of Yu the Great is jade tablet, while that of Xia Qi was the semi-circular jade. The Classic of Mountains and Seas: Classic of Regions beyond the Seas said: “At Dale Ye, Xia Qi watched the musical dance Jiudai, and drove two dragons, flying beyond the clouds. In his right hand was a canopy, in his left hand a jade ring, and on his waist wore a semi-circular jade(according to Guo Pu's annotation: 'a jade like half the sun'). Another saying goes that this happened to the north of the Dayun Mountain”. ${ }^{27}$

As the royal emperor, why Qi of Xia was described as "in his left hand a jade ring, and on his waist wore a semi-circular jade"? Seen from the great tradition of 8,000-year-long jade culture, the appearance of jade tablet was much posterior to that of semi-circular jade. In other words, compared with the jade tablet of Yu the Great, Xia Qi's semi-circular jade bears more historical roots, whose cultural implication was also very rich. In 2007, the tomb No. 23 (M23) discovered at Lingjia Tan, Hanshan County, Anhui Province, showed the splendid jade bearings of a tribal leader 5,300 years ago: each of his hand wore 10 jade bracelets and on his body more than 300 jade articles, including a large number of semi-circular jades. This shows, the description of Xia Qi in The Classic of Mountains and Seas has a deep historical support, and isn't imagined or created mythological literature at all. The custom of the ruler's wearing jades 4,000 years ago resulted from the prehistoric tradition that tribal rulers' wearing jades around 5,000 to 6,000 years ago. What requires for further research is the mythological concepts behind the custom of wearing jades. Compared with the hundreds of jade articles discovered in the high-level tombs of Liangzhe Culture or Lingjia Tan Culture, Yu the Great and Qi of Xia only had one or two symbolical jade articles, as though representing the situation after the peak of jade culture or showing that jade culture tended to decline after the peak. The reason was that, with rise of state powers in the Central Plains, a new holy ironware (the bronze ware) appeared and gradually became popular. The great tradition of jade's domination transferred to the little tradition of co-existence of gold and jade.

The mythological concept behind the custom of rulers' wearing jades is mainly connected with the wizards' or priests' professional demand of access to the deities or heaven. In annotations to The Classic of Mountains and Seas, there are other versions about Xia Qi's entering the heaven by driving dragons. For example, Guo Pu explained: "according to Guizang: The Classic of Zhengmu, 'Qi of Xia rode the flying dragons to the heaven, which was auspicious'. Obviously, Qi was a deity too”. Guo thought that Qi of Xia, who could go to heaven, was already a god in identity. This was an interpretation of Xia Qi's entering heaven from the Taoist belief of West Jin dynasty. To the Qing dynasty, Hao Anxing cited another piece of information in his annotation: the 82nd volume of Imperial Readings of the Taiping Era cited Records of the Grand Historian that, "Qi of Xia once rode dragons to heaven. He asked Gao Yao to practice divination for him. Gao Yao said, 'it was auspicious to go there and communicate with the deities; and you will be the emperor ruling over the world'”.

\footnotetext{
27 Yuan, Ke. Collation and Annotation to The Classic of Mountains and Seas. Shanghai: Shanghai Ancient Books Publishing House, 1980. P. 209.
} 
The former 3 materials all talked about the special power of Xia Qi’s riding dragons or entering the heaven by driving two dragons. The last material also told us about the purpose of going to the heaven - "communicate with the deities”. Besides dragon driving, The Classic of Mountains and Seas also mentioned the jade articles: in his left hand a jade ring, and on his waist wore a semi-circular jade. The narration here had the meaning of origin: the source and holder of rites, music, songs and dances was Qi of Xia, the rider of two dragons. Since he could ride dragon, why did he still hold the jade ring in his hand and wear the semi-circular jade on his waist? The text didn't explain this. Referring to another narration in The Classic of Mountains and Seas, we can know that jade ring and semi-circular jade functioned as the media between man and god: according to Classic of the Great Wilderness: West, "beyond the Southwest Sea, to the south of Chi River, and to the west of Drifting Sand, a man wore two green snake-sized jades and rode two dragons. The man was named Xia Qi. He three times visited the heaven, and went back down with Jiubian and Jiuge”. ${ }^{28}$ The rites, music, songs and dances of the human world were thought to be brought down from the heaven by Xia Qi's three visits to the heaven. And the tool he used was still the dragons. When we put together the two mythological texts, we can summarize the basic formula of mythological concept of man-and-god combination which has to 3 relative themes. They are:

The heaven visitor — riding dragons — wearing semi-circular jade (or holding jade ring)

In Painting Eulogies to The Classic of Mountains and Seas written by Guo Pu of Jin dynasty, these three themes were emphasized again: "What he drove was the flying dragons, and got the Jiudai dance. What he held was clouds. What he wore was jade. His imperial virtues were spread and his powers came from the celestial and covered all the nation.” Why jade ware was combined with the theme of humans' communication with the deities or heaven? Bamboo Annals (Zhu Shu Ji Nian) also mentioned that, the special place where Qi of Xia holding rites was a dais decorated by jades: "in the winter of 841 BC, Emperor Qi ascended the throne...he feted the dunkes at Xuan Tai”. Xuan Tian (漩台) equals Zao Tai (糟台) or Xuan Tai (旋台). Both Xuan (漩) and Zao (糟) refer to beautiful jades. So the emperor's power of access to the deities has something to do with his mysterious jade articles. In his Selections of Refined Literature (Wen Xuan, 《文选》), Wang Yuanchang said in Poem Preface to Qu River: "Qi of Xia rode the two dragons on the Xuan Tai(jade dais).” In his annotation to The Book of Changes, Li Shan said: "Qi of Xia once enjoyed music at the dyke of Jin River, and built Xuan Tai(jade dais) by the north side of the river". ${ }^{29}$

Xuan Tai was a dais decorated by beautiful jades. As a dais name for Xia's emperor, Xuan Tai had more or less connection with the emperors after Xia and Shang dynasties. In his Chronicle of Emperors (Di Wang Shi Ji), Huangfu Mi wrote: "King Wu of Zhou ordered Duke Yuan to release the prisoned people and return the jades of Xuan Tai”. In his Seven Orders, Zhang Xie of the Jin dynasty wrote that, "the rails were surrounded by clouds, with green walls and trees. There were eight guarded doors and Long Tai (Xuan Tai) was the ninth one”. In later literatures, the dwellings of the deities were also called Xuan Tai. In the poem No. 10 of Guo Pu's Poetry about Immortals, he wrote: "Xuan Tai was the hat of Kunlun Mountain and wavered on the seaside of the West Sea". Kunlun, the production place of jade located in the west, was imagined as a mountain with a top like Xuan Tai. From these resources, we can see that, ancient people's memory of Xuan Tai didn't go beyond what was

\footnotetext{
${ }^{28}$ Yuan, Ke. Collation and Annotation to The Classic of Mountains and Seas. Shanghai: Shanghai Ancient Books Publishing House, 1980. P. 414.

${ }^{29}$ Fang, Shiming et al. Annotation to Bamboo Annals. Shanghai: Shanghai Ancients Books Publishing House, 2005. P. 213.
} 
described in the age of Xia Qi. So, the same as the theme of dragon riding, the mysterious theme of jade dais, semi-circular jade, jade ring etc. carried some historical information which was prior to the Shang dynasty.

\section{The Myth of King Zhou of Shang's Burning Himself Together With Jades}

The fourth jade myth is the narration about the last emperor of the Shang dynasty, King Zhou of Shang, who burned himself together with jades. According to Lost Book of Zhou: Defeat of King Zhou of Shang, "King Zhou of Shang lost the battle on the outskirts of Shang's capital. On that night, King Zhou took out five Heaven Wisdom Jades (jade of supreme beauty which didn't get warm in the fire), wore them on his body and burned himself. Some people told King Wu of Zhou that King Zhou had burned four thousand jades. Five days later, King Wu of Zhou ordered his chiliarch to look for King Zhou's body and the jades. The four thousand jades had been destroyed, but the five Heaven Wisdom Jades were still in good condition”. ${ }^{30}$

For King Wu of Zhou, who succeeded King Zhou to rule over the Central Plains, all jades could be valid evidence of the transfer of power and heaven's will and kept in the royal family, rather than destroyed or canceled like the pictures of gods, the totem or the memorial tablets. After the story about King Zhou's self-burning, Lost Book of Zhou: Defeat of King Zhou of Shang continued with King Wu's inheritance of jades: "All Heaven Wisdom Jades were treated as precious jades by King Wu. The total jades King Wu captured from King Zhou of Shang amounted to one hundred million (a million of that age is treated as 80 thousand)". Later generations have different understandings of the "one hundred million jades. Huang Huaixin, after studying various citations and annotations, concluded that, six Chinese characters were lost in the sentence. Added the six characters, the sentence meant, “All Heaven Wisdom Jades were treated as precious jades by King Wu. In all, he captured 14,000 old precious jades and 180,000 wearing jades from the Shang dynasty”. ${ }^{31}$

Whether treated as history or mythology, the narration in Lost Book of Zhou can at least show that, together with the revolution of Zhou dynasty, a large amount of jades had a new owner. Even with a conservative estimation, around 200,000 jade articles were included in the Zhou royal warehouse. ${ }^{32}$ Before its meaning of wealth and luxury, jade's higher value was to represent holiness and heaven's will at the beginning of Chinese civilization. What requires our cross-cultural view is, why those documentaries put special emphasis on numerous jades instead of gold ware, silver ware or the bronze. For the author of Lost Book of Zhou who covered three dynasties in his book, what special cultural values from the great tradition had motivated or unconsciously dominated his choice or his narrative focus (jade)?

When King Zhou of Shang burned himself, he also burn jade except the Heaven Wisdom Jades. The idea that jade can be refined also appeared in the myth of $\mathrm{Nv}$ Wa's patching up the sky. In this sense, "jade refining (炼石)” is also called “Dan refining (炼丹)”, which was an important magic in later Taoist beliefs and practices. The basic step of Dan refining was to smelt is to smelt the cinnabar in a stove. Later, Dan was divided into the internal Dan and exterior Dan (alchemy): internal Dan was refining the human body through Qigong, and exterior Dan was to smelt the medical stone with fire. Comparative religionist Mircea Eliade told people that we should focus on the mythological concepts in gold smelting or Dan refining, that is, how the materials and the spiritual interacted. 'This magic technique made the mineral 'mature', the metal 'purified'. It developed into the alchemy,

\footnotetext{
${ }^{30}$ Huang Huaixin. Annotation to Lost Book of Zhou. Xi'an: San Qin Publishing House, 2006. P. 203.

${ }^{31}$ Huang Huaixin. Annotation to Lost Book of Zhou. Xi'an: San Qin Publishing House, 2006. P. 204.

32 Yang, Shengnan. Economic History of Shang Dynasty. Guiyang: Guizhou People’s Publishing House, 1992. P. 538.
} 
since it accelerates the 'perfection' of metals”. ${ }^{33}$ In accordance to Eliade's hints, scholar Yang Rubin from Taiwan, China, attempted to interpret the root meaning of Gold, one of the Five Element, and also related to the mythological connection between alchemy and immortality belief. ${ }^{34}$

Base on "dual verification" methodology, oracle inscriptions on the bones or tortoise shells of the Shang Dynasty show that, in the hearts of Shang people, jade myths were not pure literary creation, but a valid and evidential belief and ritual narration. In his paper From Oracle Inscriptions, See Shang People's Valuing and Using of Jades and a Few Revelations, Wang Yuxin made some useful explorations into this. He pointed out, in the oracle inscriptions, the character Yu (jade, 玉) appeared so did Ya (press, 压) which combined two Yu characters. And the character Nong (play, 弄) presented an image of a hand holding a jade. Correspondently, there are physical evidences, including numerous animal decorations such as jade fish, jade birds, jade turtles and jade cicadas. This was the scene of Shang people’s “playing jades”. Another character Bao (treasure, 宝) was combined with Bei(cowry, 贝) and Yu (jade, 玉), which shows that the slave owners of Shang dynasty had been conscious of regarding jade as treasure. "In Shang dynasty, since people treasured and loved jades, the shamanism and mystification of jade took its shape. The nobility even dreamed of jades”. ${ }^{35}$ The royal nobles also used jades as the presents to the deities in their rituals. This kind of jade ritual was a transition from prehistoric jade culture and custom to the later tradition of jade rites system lasting from West Zhou dynasty to Han dynasty ${ }^{36}$ which laid the foundation for the core contents of Chinese ritual culture.

\section{The Myth of Jiang Ziya's Knowing Heaven's Will by Gaining a Semi-circular Jade}

The fifth case is the myth that, Jiang Ziya of the West Zhou dynasty gained a semi-circular jade. According to the first volume of Shangshu Dazhuan, "King Wen of Zhou arrived at the Bo river, where he saw Lv Shang (Jiang Ziya) fishing”. Lv Shang went to present himself to the King Wen. Lv Shang said: "I fished a semi-circular jade. I saw words on it: the heaven's will is to let King Wen of Zhou rule over the world and Lv Shang will help him.” Later, semi-circular is often cited to refer to Lv Shang’s assistance to Kong Wen of Zhou. For example, in Epitaph for Zhou's General Zhao Gong, Geng Xin said, "the land produced a good harvest and by the time, wars had ended. The semi-circular jade (with the assistance of Lv Shang, the King Wen of Zhou's son) stopped the chaos, and the gold glimmering in the court”. In his poem Officer Li of West Zhe Expressed His Dream in a 40-line Poem, Liu Yuxi said: "His family have the stove supported by gold pillars (signifying officers important to the country), and the semi-circular jade talent (signifying outstanding talent in assisting the emperor and administering the country)”. In his Yujia'ao: Poem Written on the Painting of Feng Jiang River's Fisherman, Sun Zhiwei of Qing dynasty said: "He was happy that he had fished the semi-circular jade. It was time for him to stop fishing and fight for the people's welfare”. These ancient poems and citations are enough to show the popularity and re-creation of Jiang Ziya's jade fishing myth in later literature. But, if we want to know more about the practical functions of jade articles in West Zhou dynasty, we need to consult to the historical records. According to the article Gold Case in Shang Shu:

\footnotetext{
33 Eliade, Mircea. Immortality and Freedom. Trans. Wu, Xishen. Beijing: China Zhigong Publishing House, 2001. P. 323.

${ }^{34}$ Yang, Rubin. Violence/Order, Transformation, and Immortality: The Root Metaphors of Gold. Tsinghua Journal of Chinese Studies. Vol. 38 (04). Dec., 2008. Pp. 677-709.

${ }^{35}$ Center for Chinese Archaeology and Art, The Chinese University of Hong Kong. East Asian Jade: Symbol of Excellence. Vol. 1. Hongkong: Centre for Chinese Archaeology and Art, CUHK, 1998. Pp. 18-25.

${ }^{36}$ Sun, Qingwei. Research on the JadeSystem of Zhou Dynasty. Shanghai: Shanghai Ancient Books Publishing House, 2008.
} 
Two years after defeating Shang, King Wu of Zhou got sick and there was no sign of recovery. Two dukes said, “let's practice divination for King Wu”. Duke of Zhou said, “why don’t we pray for our king?” Duke of Zhou made himself the sacrifice, and built three altars. He also built an altar on the south side. Duke of Zhou stood there, facing north. He held a Bi (round flat jade with a hole in its center used for ceremonial purposes in ancient China, 璧), and a Gui (an elongated pointed tablet of jade held in the hands by ancient rulers on ceremonial occasions, 珪), and prayed to King Tai, King Ji and King Wen (they all were ancestors of the royal family, including King Wen was King Wu's late father ). The official historian wrote down his prayers: "Your eldest grandson Ji Fa (the name of King Wu) has got a serious disease. If you three have sacrifice duty in heaven, please make me the sacrifice instead of Ji Fa. I'm kind and talented, I can serve the gods. Your eldest grandson is not as talented as me, so he's not good for serving the gods. It's the heaven's will that ordered Ji Fa to rule the country and win the world, so that he could ensure peace and prosperity for your precedents. All the people love him. Please don't disappoint the heaven's will. Thus you, our ancestors, can forever have honors. Now, I have given orders to the holy turtle. If you answer my appeal, I will offer the Bi and Gui to you; if you don't, I will take back the Bi and Gui”. Then, he practiced divination to 3 turtles, they all told auspicious results. He opened the writing bamboo slips, the outcomes were all auspicious. ${ }^{37}$

Jiang Ziya knew the heaven's will and orders from the semi-circular jade which was bestowed by the heaven. Duke of Zhou used the jade articles as a precious bribe and bargain with his ancestors to ask for their blessings. The scene how people talked to and communicated with the gods or supernatural beings, though happened 3,000 years ago, was still as vivid as we can see.

\section{The Myth of King Mu of Zhou's Gaining Jade Flowers and Jade Leaves}

The six case is the story about King Mu of Zhou, who went to visit the Palace of Yellow Emperor and gained jade boughs and jade leaves. According to volume two of Tale of King Mu, Son of Heaven, "on a good day of Xin You year, King Mu climbed up to the Kunlun Mountain, to visit the Palace of Yellow Emperor”. Here, the Palace of Yellow Emperor was basically the same location where, the Yellow Emperor ate the jade cream and planted the jade buds as in the first case's citation from The Classic of Mountains and Seas: Classic of the Mountains, West, which can remind people of jade halls-palace in the moon. The Palace of Yellow Emperor may be the palace of worshiping gods with jades, the so-called the place where "all gods and ghosts feed on jade”? King Mu of Zhou traveled such a long way to Kunlun Mountain, to the Palace of Yellow Emperor, which contained the meaning of return to the prehistoric jade culture. Comparing Duke of Zhou's offering jades to the gods and King Mu of Zhou's worshiping the river god with jades, we can see the sincerity and respect in the kings' hearts when they worshiped the gods with jades. In these solemn sacrifice rites, the jade myths is more of a belief and concept, instead of pure literature or stories.

Where did King Mu get the precious jade flowers and jade leaves?

According to The Classic of Mountains and Seas: "Clear water springs out of the Chong Mountain, which is warm and windless. Flying birds and various animals feeds here. Former kings called it 'Xian Pu' (the Fairyland). The Son of Heaven (King Mu of Zhou) got the flower buds of jade boughs here”. According to the old annotation: "jade bud, the essence of jade. According to Shi Zi, 'there are jade buds in the Dragon Spring'. According to The Classic of Mountains and Seas, 'the Yellow Emperor took the jade flowers of Mi Mountain and planted them on the south side of Zhong Mountain’”. Du Qi said: “Shi Hua said: ‘At the beginning of all jades, there are buds, flowers and blooms' Buds are the very beginning of jades' birth, as the buds of grasses and trees; flowers are the

\footnotetext{
${ }^{37}$ Ruan, Yuan. Annotations to 13 Confucius Classics: Annotations to Shang Shu. Shanghai: Zhonghua Book Company, 1980. P. 196.
} 
most beautiful status of jades, like the flowers of grasses and trees; blooms are the newly maturity of jades, like the blooms of grasses and trees”. ${ }^{38}$ The treasure King Mu gained also came from the water. The jade buds, jade flowers and jade blooms can be produced from the water and planted the same as crops, which conveyed most naïve and pure ideal of ancient people. They grew year by year, and came back to life when the spring came. The jade trees and jade flowers on the mountains became the symbol of immortality and eternity of human beings. Since the Stone Age, jade had been the symbol of eternal life, and that was why it had such a high status in the hearts of ancient people. Then, how did it become the medicine for immortality?

The health care function of jade had long been talked about by ancient people. According to The Huannanzi, “Boil the jades from the Zhong Mountain for three days, yet the color of jades won't change, because they have got the essence of nature”. In Baopuzi, Ge Hong said, "people who eat metals will live as long as metals, and people who eat jades will live as long as jades”. Yu was also called “Xuan Zhen (magic essence, 玄真)”. Eating Xuan Zhen, your body will become light as flying, and people who eat it will have an everlasting life.

In Introduction to Herbs, Tang Shenwei of Song Dynasty said: "jade powder has a mellow taste. It's non-toxic. It mainly helps to remove the heat in stomach, heel the wheezing, the dysphoria and thirsty. Eating bean-sized jade regularly, you will feel light and live longer. Jades are born in Lantian and can be picked in any season of the year", it also cited the prescriptions from many sources, including Views on the Treasure, The Qingxiazi, Anecdotes during Tianbao Reign, etc. ${ }^{39}$ In Compendium of Materia Medica, Li Shizhen recorded 14 medical functions of jades, including healing the heat in stomach, the wheezing, the dysphoria, the thirsty, and eating bean-sized jade regularly, you will feel light and live longer. He also cited from other books that, jades can help smooth the lung, clean the throat, and flourish the hair. For scars on the skin, grind them every day with a real jade, and the scars will disappear gradually. ${ }^{40}$

The previous 6 jade myths lasted from the legendary Chinese ancestor Yellow Emperor to the kings of three dynasties — Xia, Shang and Zhou dynasties, covering a time span of more than 2,000 years. From the analysis of them, we can see the continuation and evolution of jade's mythological concepts, from the prehistoric great tradition to the civilized little tradition.

\section{Jade as Treasure: The Social Integration of Material Worship and Formation of Civilization}

If we try to answer how the magic weapon in literature came into being, the answer will definitely go beyond the scope of literature and enter the territory of religion: they are magic weapons because they themselves have supernatural powers, magic powers or superhuman powers. If something is thought to have supernatural powers, it can be called "fetich" or "fetish". A deity can be various concrete and sensate object, which could happen earlier than the abstract concept of god. This is the idea proposed by French thinker De Brussels in his book Idol Worship for Gods or the Similarity between Ancient Egyptian Religion and the Living Negro Religion. The publish of this book in 1760 made the religious terms "fetish" and "shamanism" popular in the academic circle and was broadly spread. Brussels wasn't content with the current theories on the origin of mythology and religion.

\footnotetext{
38 Gui, Qi (Qing Dynasty). Annotation to Shuo Wen Jie Zi. Vol. 2. Shangdong: Qilu Publishing House, 1987. P. 29.

39 Tang, Shenwei (Song Dynasty). Introduction to Herbs. Vol. 3. The first editon of 4 book series.

${ }^{40} \mathrm{Li}$, Shizhen (Ming Dynasty). Compendium of Materia Medica. Vol. 8. Stones No. 2: Jade. Taiwan: The Commercial Press, Ltd., 1986. Pp. 626-629.
} 
He hoped to explore the origin of mythology and reveal the principles and rules hiding behind Greek mythology with the help of the beliefs held by no-western uncivilized nations. According to this book, the universal pattern of human's religious development can be expressed with a syllogistic model:

Shamanism—polytheism—monotheism

As for the worshiping object, Brussels wrote: "the two parts of paganism are, either the worship for stars which we call as star worship, or worship for certain secular thing or material object, which we call as 'fetish' as what's among the African black people, as I call it—-shamanism'. I want to get used us this word 'shamanism'. Although it original means the religion of black people, when I use it, it also refers to other nations' worship for the animals or lifeless objects. These things are deified, even when they are not deities, they already have the characteristics of deities, for example oracles, amulets, magic weapons etc. What can be sure is that, these though patterns share the same origin, which belongs to a common religion, which has long been spread over the whole world. It can only be explained by itself. Among various religions of the paganism world, it belongs to an independent type". ${ }^{41}$

From the talk between Fenghuzi and King of Chu which had the judgment that "jade is also a deity", to Xu Shen's explanation of Ling (deity or god) as "the witches use jades to worship gods. Ling may be connected to witches", in the early stage of Chinese cultural history, the functions of jades basically conformed to the religious definition of shamanism. If we rename the mythological concept behind the Chinese jade customs or rites, we can call it "jade religion". This point of view may help us us understand why the values of Chinese civilization differed from the western "gold worship" in the very beginning. In simple words, for Chinese civilization, jade the holiness of jades was native, original and spontaneous, while the holiness of gold was derived after jades, and was more or less influenced by the foreign cultures, including the mining technologies and mythological concepts of metals.

When writing the book The Origin and Growth of Religion, the founder of comparative religion teaching, Max Müller had to specially spend a whole chapter (Chapter Two) to discuss whether shamanism is the original form of religion or not. Müller studied the research works on shamanism during the almost 100 years since Brussels, and came to 4 key points:

(1) The meaning of deity has been unclear since the start of its use, which has been widely used by most scholars, so it includes all symbolic or imitative images of objects worshiped in the religion.

(2) In historical nations, we found that, all under the category of deities have there is historical and psychological causes. So we have no reason to exclude any nation, or think that shamanism only exists in nations we don't know about their religious development.

(3) No religion is totally unconnected to shamanism.

(4) No religion is totally shamanism. ${ }^{42}$

Müller thinks admitted that shamanism has cross-culture commonality, but he disagreed to regard shamanism as the origin or primitive form of religion. He reminded people to look for the concept of superhuman power prior to the concrete object or material. Compared to superhuman power, fetish is merely the appearance

\footnotetext{
${ }^{41}$ Max Müller, Friedrich. The Origin and Growth of Religion. Tran. Jin, Ze. Shanghai: Shanghai People’s Publishing House, 1989. Pp. 40-41.

${ }^{42}$ Max Müller, Friedrich. The Origin and Growth of Religion. Tran. Jin, Ze. Shanghai: Shanghai People’s Publishing House, 1989. P. 82.
} 
derived from inner concepts. ${ }^{43}$ According to this idea, we need to further explore how the deities or superhuman powers infiltrated into the materials like jade, gold etc. By analogy to anthropologists' mythological concept of the deification of gold, the deification of jade can be interpreted like this: the color and lustre of sky are the same as that of jade, so the sky is imagined as being made of jade. This is the base of taking jade as the symbolism of heaven, heaven's will, or the “De (德, virtues)”. What needs to be analyzed is, during the Xia, Shang and Zhou dynasties, the concept of "De" was also a mythological concept, which was connected to the holy heaven's will. It was after the recreation of Confucianism that "De" evolved into a moral concept. For example, in the poem Xiao Yong, included in Classic of Peotry: Odes of Qin, "speaking of a gentleman, he shall be gentle as a jade”; in the notes written by Zheng Xuan, "jade has 5 virtues”; in his memorial to the throne, Kong Yingda cited from Etiquette in Appointing Officials, "a gentleman compares his virtues to the jade: jade is warm and humid, that means a gentleman shall have 'benevolence'; jade is fine and exquisite, that mans a gentleman shall have 'wisdom'; jade is clean but not discriminating, that means a gentleman shall have 'righteousness'; a hanging jade is like a drop, that means, a gentleman shall have 'propriety'; jade is trusted by the surroundings, that means, a gentleman shall have “trustworthiness””. In Commentary to the 5 Classics (《五经通义》), the 5 virtues were explained differently: “jade have 5 virtues: jade is warm and humid, similar to 'wisdom'; jade is sharp but not harmful, similar to 'kindness', jade is suppressed but doesn't give in, similar to 'righteousness'; if jade has any flaw inside, the flaw will be shown, similar to 'trustworthiness'; a hanging jade is like a drop, similar to 'propriety'”.

The development of jade-as-god to jade-as-virtues was the result of recreation when the mythological concept of great tradition entered into the little tradition. Thought its concept transferred from the religion to the moral virtue, the essence of jade-as-virtues didn’t detach from the mythological concept. Myth mythology hace a valid root in Chinese great tradition, whose role in constructing the Chinese identity can't be undermined. The formation of an integral national identity by integrating a large number of people with different living environment, different languages and races on a large geological area is a key factor that Chinese civilization can come into being and last for thousands of years. How did such a large social identity come into being? Japanese scholar Shinichiro Kurimoto viewed the history from the perspective of economic anthropology, and promoted Browne's "the patterns of integration” which consist of 3 patterns - "reciprocity", "redistribution” and "market exchange". Under the circumstances of reciprocity and redistribution, the social system which was formed under the patterns of integration is closely linked to the etiquette and religion. So these social systems plays the role of coordinating and integrating people's ways of socializing and consolidating the social structure. Thus, "the patterns of integration" is that determines all the social behaviors within the social and geological boundaries, rather than a mere set of concepts which only exist in the economic scope. Therefore, we can find the social borderlines as long as we can ascertain the reciprocity and the redistribution behaviors. ${ }^{44}$

On the eve of the Bronze Age, jade was the main product that constructed the spiritual authority in Chinese society. The integration of the former three patterns was accomplished during the interaction in trading jade resources from the local production places of jade to the Central Plains. After the coming of the Bronze Age,

\footnotetext{
43 Max Müller, Friedrich. The Origin and Growth of Religion. Tran. Jin, Ze. Shanghai: Shanghai People’s Publishing House, 1989. P. 84.

${ }^{44}$ Shinichiro, Kurimoto. Economic Anthropology. Trans. Wang, Ming, et al. Beijing: The Commercial Press, 1997. Pp. 49-50.
} 
redistribution happened among the old jade trading areas, adding the spatial distribution activities of new metals (gold, silver, copper, tin, lead etc.). Anthropologist Zhang Guangzhi thought that, Shang dynasty moved its capital for 8 times, all of which were connected with the search for copper minerals. In Tale of King Mu, Son of Heaven, we can see that, during his travels to the west, King Mu had economic relationships with the leaders of other tribes, which centered on the reciprocity or "market exchange” of awarding jade articles ore metal wares, or seeking jade materials etc. Viewing from this, we can see, how the demand of holy treasure (jade) which was infiltrated with mythological beliefs had functioned as the basic motive to the economic and social integration of the kingship in the Central Plains and the neighboring tribes around it. Thus, by referring to Browne's "the patterns of integration", our research on Chinese national identity can be expanded to a new horizon: at the turning point to the civilization, how jade articles functioned as the bonding that integrated the Central Plains and the large area around it? Such bonding was both material (from the mining, exploitation, transportation, exchange to the processing and distribution of jade minerals), and spiritual (the cross-region spreading and unification of jade's mythological concept). The long-term interaction of material and spiritual demand finally brought to the eve of Chinese civilization (the era before the Bronze Age) its core values: jade as holy, jade as treasure, and jade ware as the sign to communicate man and heaven (man and god).

\section{Mythological Genes of Chinese Identity}

The social integration was characterized of the wide spreading of jade's mythological concept, i.e. the shamanism of jade. Now that this integration forged the core values of Chinese civilization's roots, what role did these core values play in the formation of Chinese identity? Clues to this question's answer can be found by the path of shamanism research methods in comparative religion studies. Max Müller proposed that, "if we want to understand, more than just know, the ancient style of uncivilized peoples, we must try very hard to distinguish. Sometimes, a log or a stone is worshiped, because it belonged to an obsolete altar, or a trial place in the ancient; sometimes it represented a spot where a great battle or murder happened; sometimes it belonged to certain king's tomb; sometimes it guarded the holy border of a race or clan”. Some stones can be used to make weapons, some to sharpen weapons; and some are jade stones discovered in Swiss Lake which are treasure imported from a faraway place and handed down from ancient times and; some are meteorites fallen from the sky. For various reasons, the ancient people, even modern people, treat them with respect. And can we simply call them as fetishes?” 45 Müller hoped that researchers can penetrate through the appearances and find the conceptual elements which deified these fetishes. Such research requires comparative mythology's detailed analysis. Zuo Zhuan related to “Qi of Xia's semi-circular jade”, which bore the cultural memory of the lost Xia dynasty and its great king. What role did the jade mythology play in constructing the core values? And how does this role lead to Chinese historical and cultural identity through the unified memory of jade and the great king?

Through the analysis of the former 6 jade myths, we can have a full grasp of the ideological meaning of mythology. Here, we can cite the narration of religionist Frederick J. Streng: "What's mythology? Why does it have some much charm? Mythology is the story about the supernatural beings. It, by means of symbolic creativity, brings order to human's existence and meaningfulness to the world. Mythology has another concept of

\footnotetext{
45 Max Müller, Friedrich. The Origin and Growth of Religion. Tran. Jin, Ze. Shanghai: Shanghai People’s Publishing House, 1989. P. 69.
} 
being the supreme values for people who live in orders and regulations." ${ }^{46}$ What Streng stressed is, the ideological function of mythology created certain orders of the real world with supreme values and meaningfulness among certain cultural groups, and subconsciously dominated the concept and behavioral choices of every member in this group. These are the "core values” people are looking for, also what Max Weber wanted to achieve through scientific social studies — "to connect the real cases, be it conscious or unconscious, with the common 'cultural values'”, and then to identify and determine the special coding system of the culture. The previous comparative studies show that: gold myths were the stereotype code in constructing the value world of western civilization, similar to the jade myths which functioned as the stereotype code in constructing the value world of Chinese civilization. Through the comparison between the gold (gold bough or gold lamb hair) search in Greek mythology and the jade search in Chinese mythology (King Mu's long journey to the Yellow Emperor Palace, the Queen Mother of the West's jade lake [Yaochi, 瑶池], the peace jade wanted by King Zhao of Qin; the jade imperial seal passed from dynasty to dynasty), we can have a clear comparative interpretation of the different values between the western and the Chinese mythologies at the very beginning. According to the comment of Peter Berger, a contemporary knowledge socialist, they are different social realities constructed by different mythological systems, written in his book The Social Construction of Reality.

The sociology of knowledge must not only deal with the empirical "knowledge", but also the various processes during which all these knowledge was constructed into the "reality". ${ }^{47}$

On the theory of mythology's constructing the reality and reforming the social life, the religionist Frederick J. Streng had penetrating analysis. He reminded the researchers to focus on production mode of mythology and rites, as the sign symbols, which accomplished essential spiritual transformation by way of holy symbols. The representation can be generalized with a five-stage schema:

(1) The imperfection of human's circumstances: the imperfection of the secular world.

(2) The supreme entity — the holy kingdom: the source of orders and internal values.

(3) Essential spiritual transformation: the holy power was represented in the existences (creations) by way of the mythological discourses or actions, which could be copied by holy orders practiced by humans (the priests or witches) and became the patterns of daily lives.

(4) Individual representation: by way of worshiping ceremonies or rites, to gain the meaning of life and the strength of action from the holy kingdom.

(5) Social representation: individual lives were integrated into a whole social entity, to show the essence of all individuals' existing through the way of regularly repeating the holy discourses and postures and living the daily life according to the ideal in holy stories or moral lessons. 48

The ideology of jade mythology includes concepts like regarding jade as god, as the symbol of celestial bodies, as the symbol of immortality etc., sorcery rites and practices like worshipping gods or the ancestors with jades, legends and stories which value jades, ideal morals (the virtues of jade) and teaching or learning method (cutting, grinding, carving and polishing) extended from jades, the social customs of wearing jades (a gentleman

\footnotetext{
46 J. Streng, Fredrick. Understanding Religious Life. Trans. Jin, Ze; He Qimin. Shanghai: Shanghai People’s Publishing House, 1989. P. 69.

${ }^{47}$ Berger, Peter; Luckman, Thomas. The Social Construction of Reality. Trans. Wangyong. Beijing: Beijing University Press, 2009. P. 3.

${ }_{48}$ J. Streng, Fredrick. Understanding Religious Life. Trans. Jin, Ze; He Qimin. Shanghai: Shanghai People’s Publishing House, 1989. P. 67.
} 
must wear jade), linguistic customs formed from the supreme values of jade — naming people from jade or jade articles (from Jade Girl一玉女, Xie Xiang一撷项 to Qiong Yao-琼瑶, Tang Guizhang一唐圭璋), numerous Chinese characters produced with the jade (玉) as the radical, various idioms and proverbs with jade myths as the core values etc. Through the spreading and interaction of cultures, all these aspects did not only form the life reality of the state in the Central Plains, but also became the identity target shared by many kingdoms and tribes beyond the Central Plains ${ }^{49}$, thus helped to construct the fundamental factors of Chinese cultural identity, and had functioned as the visible or invisible identity several thousand years prior to the First Emperor of Qin’s unifying China. It can be further proven by the prosperity of jade production in Dawenkou Culture in the east, Qijia Culture in the west, Hongshan Culture in the north, Lingjiatan Culure in the south, and Liangzhe Culture, Shijiahe Culture, and the commonality of jade articles, such as Huang (semi-circular jades), Bi (round flat pieces of jade with a hole in its centre (used for ceremonial purposes in ancient China), Qiong (fine jades) etc.

After the Shang and Zhou dynasties, the ideology of civilized nation became different from that of the oral mythology, during which the change of basic media play the key role. With the help of characters and writings, mythology in narrations and performances was fixed as the classics, which could be readily read by a large number of social members. The range and scale of spreading was largely expanded. It was in a large area, instead of the small area limited in tribal boundaries, that the characters and writings functioned as the linking bridge to unify the cultures of different regions and form a wholesome, and general knowledge. In Shuo Wen Jie Zi, 124 Chinese characters have the radical Jade (Yu, 玉), most of which are the technical name of jades from places of all directions. This conforms to the vast geographic distribution (140 mountains producing jades) of jades as recorded in The Classic of Mountains and Seas. Inspired by Shuo Wen Jie Zi's high emphasis of jade characters, the Volume 30. Of the new character book ${ }^{50}$ was name as "Yu Pian (玉篇, Jade Characters)". ${ }^{51}$ The later generations followed their steps, even using "Yu Pian” to refer to all Chinese characters in a general sense. For example, in his poem Old Residence of Princess Shengping, Luo Yin of the Tang dynasty said, “An immortal rode a Feng ${ }^{52}$ and landed here. And I just finished writing the characters (Yu Pian)”. And in Volume 7 of Xixiang ji zhugongdiao, “...know all the passages... remember all characters (Yu Pian)”. All these characters and cultural or geographic reports related to jades can be analyzed and studied from the perspective of Chinese identity. However, so far, no such studies has been done. Researchers of the mythology circle can make more efforts to bring mythological studies into the field of Chinese intellectual history. As Streng suggested, “to realize this, we should discuss the myths, the rites and the important of holy discourses, because they created the entity and gave people the power to get rid of long-lasting and slowly-changing disorders which was characteristic of fear, failure to find the original and deepest source, failure to see the values and meanings etc."

\footnotetext{
${ }^{49}$ Yang, Jianfang. Research on South China's Pre-historical Cultural Spreading and Influence Through the Jade Articles. Southeast Culture, 2008 (04). Nanjing: Nanjing Museum, 2008.

50 A book about Chinese characters, which was written by Guo Yewang et al. of the Liang dynasty of Nanchao period.

51 History of Nanchao: The Biography of Guo Yewang, "first, Doctor Guo Yewang was order to write Yu Pian (Jade Chapter), but Jian Wen thought it was not well writeen. Since Xiao Kai was knowledgeable, he was ordered to edit the writings of Guo Yewang".

52 Feng (凤), an holy and supernatural bird in Chinese mythology. Later, Feng becomes the symbol of noble females, especially the empress, princess, etc.

53 J. Streng, Fredrick. Understanding Religious Life. Trans. Jin, Ze; He Qimin. Shanghai: Shanghai People’s Publishing House, 1989. Pp. 66-67.
} 
The above discussion is based on my trial to explore the great tradition and core values of Chinese culture from the perspective of native special mythological resources. Research from this perspective seems deficient and weak, because the new archaeological discoveries of prehistoric jades are galvanizing enthusiasm in the antique archaeological and collection circles, but the mainstream academic circles (arts, history and philosophy, especially philosophy and intellectual history) are neglecting these for their lack of interdisciplinary knowledge. On the other hand, the principle structure which was built on the eastward transmission of western sciences has vastly blocked the local or native cultural reality. So, for those researcher who have learnt western philosophical theories, and then come back to study "Chinese philosophy" who actually has no word for "philosophy", jade mythology is totally ignored. Since philosophy is a metaphysical, abstract, conceptual habit, they are forced to find the counterparts to western philosophical categories in ancient Chinese classics as the only way to explore Chinese intellectual heritage. However, they get stuck in the narrow little tradition of Chinese characters and writings, fail to have an insight to the cultural great tradition hiding behind them. So they cannot find the mythological beliefs, which are the cultural genes and stereotype codes, through the great tradition whose time span is two times longer than the little tradition.

The multi-volume works Chinese Intellectual History starts from the official schools of the West Zhou dynasty, but doesn't cover the pre-Zhou civilization. Up to the 21st century, a new team-work book, Chinese History of Ideas offers a "Table of Chinese Ancient Philosophical Categories", which includes 78 categories in, ${ }^{54}$ covering various aspects from the heaven's will (natural law) to social events, but nothing related to jade. This means, Chinese history mythology which has lasted for 8,000 years, from the early jade articles created by ancient people in Xinglongwa Culture that manifests their worship and appreciation for jades to Cao Xueqin's jade-related novel The Story of the Stone (also translated as A Dream in Red Mansions), got lost in the modern context of eastward transmission of western sciences. The loss or negligence of Chinese civilization's core values by modern intellectuals is connected to the dominance of western discipline schema and the thought patterns which lack the consciousness of local culture. The researchers, being unfamiliar with the "coding language" of jade culture, don't explore the value system of Chinese character coding, but try to mechanically match Chinese philosophy with foreign categorical system, such as “ontology”, “epistemology”, “materialism”, "idealism" etc. As a result, they get stuck in a bunch of "-isms" and lose the possibility to grasp the core of native cultural.

The reflection on why Chinese core values are neglected in modern society requires an examination on the methodology of cross-culture knowledge, and a full consciousness of current method's defection, so to avoid the false match. Character books like Shuo Wen Jie Zi, which can well display Chinese core value system can be re-examined, re-valued and re-evaluated by a comparison with the richness and diversity of jade articles, the antiques handed down from the great tradition. Thus, we can see the whole network of jade rites and practices from Xia and Shang dynasties to Qin and Han dynasties. Xue Daoyun once pointed out that, there are two sacrifice systems—Jiao Ti (郊褅) and Zu Zong (祖宗), which are quite different in nature:

Jiao Ti is sacrifice to the gods. It's held on the hillock in the royal animal park. The media are the witches, and the sacrificial vessel is jade.

54 Zhang, Dainian. Chinese History of Ideas. Zhengzhou: Zhongzhou Guji Chubanshe, 2005. P. 13. 
$\mathrm{Zu}$ Zong is sacrifice to the ancestors. It's held in the ancestral temple of a ruling house. The media are the descendants. The sacrificial vessel is vibrant of daily vessel.

According to the above differences, the practices in Hongshan Culture and Liangzhe Culture ought to be Jiao Ti to honor the gods, while those in Yangshao ought to be $\mathrm{Zu} \mathrm{Zong} \mathrm{to} \mathrm{honor} \mathrm{the} \mathrm{ancestors.} \mathrm{The} \mathrm{first} \mathrm{combination} \mathrm{of} \mathrm{two}$ sacrifice systems may be in Rangfentao Temple; the Shang people honored their ancestors before honoring the gods, which was the summit of ancestor worshiping; the Zhou people again worshiped both the gods and the ancestor, combing Jiao Ti and Zu Zong; till the Ming and Qing dynasties, Tai Miao (the Imperial Ancestral Temple) and Tian Tan (Temple of Heaven), Di Tan (Temple of Earth) still co-existed. ${ }^{55}$

Whether it's proper to divide the sacrifice to gods and ancestors still remains to be further discussed, since our previous citation from the article Gold Case in Shang Shu showed that Duke of Zhou bargained with his ancestors with jades as the media, which invalidate Xu Daoyun's idea that jades were used to sacrifice to gods, not to ancestors. But, Xu viewed the national sacrifices from Shang and Zhou dynasties to Ming and Qing dynasties by connecting the sacrifice system with the unearthed prehistoric rites and places, which represented that he had got rid of the little tradition's limit and had a deep insight into the great tradition. Especially that he grasped the inheritance of jade spirit in Chinese rites, which has a much longer history than the inheritance of Chinese characters and the bronze ware. This is very valuable.

In explaining the causality between prehistoric jade mythology and jade production, two stances are at loggerheads - materialism and conceptualism. The focus of argumentation is, which one comes first, that is, which is the cause and which the result? They hope to settle the argument through revealing the interaction between concept and material. Where there is no gold, there will be no gold worship. In this sense, material determines concept. Conversely, where there is no worship for gold, people won't start mining gold. In this sense, concept determine actions. How the "god is holy" concept came into being was no literary incident, but an incident of social, group belief, a belief that influenced the East Asia region.

\section{Conclusion}

First, research on the origin of a civilization is more than making a chronological table and arranging various cultural invention in order, but also exploring the core values formed along with the birth of this civilization, especially the cultural features particular to it. Jade mythology can be the key to open how Chinese civilization came into being in its special fashion.

Second, the long history of jade mythology can be verified by the unearthed prehistoric jade articles. This can expand the mythological studies which used to be constrained in the domain of character and text studies. The research can be done from multi-principle perspectives, archeology, religion, anthropology etc.

Third, the critical link between mythology and cultural identity lies in the special cultural factors that mold the ideology. When we explore into the genes of a culture, we can grasp the core values of a special society during the interaction between material and concept, thus exploring the identity factors that unified multi-elements.

Fourth, for the identity genes of Mediterranean culture, there are a series of mythological concepts originated by the gold worship, such as the gold age, the identity of god and gold, the gold magic weapons etc.

\footnotetext{
${ }^{55} \mathrm{Xu}$, Daoyun. "Gods and Ancestors". Spirit of Jade and Soul of Nation-Collected Works from Academic Seminars on Ancient Chinese Jades and Traditional Culture. Edit. Fei, Xiaotong. Beijing: Yanshan Chubanshe, 2002. P. 18.
} 
The new horizon for civilization origin studies is to connect the mythology of holy articles and cultural identity, and describe the constructing process of core values. Modern scholars' research on unearthed gold antiques formed a cultural identity that is trans-nationality and trans-national-borders- “the Mediterranean civilization”. Similarly, research Chinese prehistoric jade articles also formed a cultural identity that is trans-nationality and trans-national-borders- -East-Asia civilization”, whose body was the Chinese civilization and also developed in surrounding areas.

Fifth, the cultural identity genes of Chinese civilization can be reduced to 5 mythological concepts, whose chronological orders are as follows:

(1) The birth of jade mythology: represented by Xinglongwa Culture in the north and Peiligang Culture in the Central Plains. The belief that "jade is heaven" and that "jade is god" is fundamental to the creation of Chinese identity. This is the embryonic period of core values, which appeared around 8,000 to 7,000 years ago. The two Cultures respectively produced jade and turquoise articles.

(2) The mythological concept of "unity of man and god" which formed on the premise of "man-and-god communication". To communicate with the heaven or god under the help of jade was the source of Chinese rites-and-music culture. It was 7,000 to 6,000 years ago, represented by the appearance of Huang (semi-annular jade pendant), which was one of the 6 musical instruments recorded in Rites of Zhou. Evidences can be found in Hemudu Culture, Yangshao Culture, Daxi Culture, Hongshan Culture etc.

(3) Totem worship which is represented by mythological animal, such as dragon, Feng, turtle, Kylin, snake, frog, cicada, silkworm. It were 6,000 to 5,000 years ago, and was represented by Double-Dragon-Head Huang of the Hongshan Culture.

(4) Mythological geographic concept which is characteristic of “Tian Xia (天下, land under heaven)”. It was 5,000 to 4,000 years ago. In later classic, it's described as "Yu the Great's remains" (Shu: Establishment of Politics); or "Yu the Great's land" (Classic of Peotry: Lesser Court Hymns-Xinnan Mountain), "nine-state island”, "holy state” etc. In the article The Fourth Year of King Xiang's Reign of Zuo Zhuan, the writer said, "Yu the Great's remains are boundless. On the map, we see it as a nine-state island".

(5) Mythology of holy kings or holy people which is represented by Yao, Shun and Yu the Great. It was 5,000 to 4,000 years ago. The predecessor was jade statue in the shape of holy man that can communicate with god or heaven. After Shang and Zhou dynasties, people re-create the ancestral mythology of 5 kings which began with the Yellow Emperor. Such mythology is represented by Taosi Culture and Longshan Culture.

In the age when The Classic of Mountains and Seas, Classic of Poetry and Songs of Chu came out, the little tradition of literal narratives merged. The great tradition, as the coding basis, was very influential on such little tradition. And the jade mythology can be found in many parts of these works. The great deal of documents listed in previous text should draw further reflection.

According to the division of great tradition and little tradition, we can also analyze and arrange Chinese prehistoric mythology into 3 cultural levels: pre-Yangshao Culture (worship for jade god—jade pieces and Huang), Yangshao Culture age, (the incubation period of jade mythology—jade lock, Huang, and Bi), Long Shang Culture age (formative period of jade mythology—Qiong, Zhang, and Gui). 
Max Weber, pointed out that, "The supreme gold of social sciences is not to pursue the construction of new ideas or new concepts, but to make efforts in understanding the cultural meaning of concrete historical links”. ${ }^{56}$

This paper traces Chinese identity back to the great tradition of jade mythological concepts, and tries to find out the stereotype of cultural values hidden behind Chinese civilization. I hope it will help us to re-understand the cultural meaning of the little tradition, that is, Chinese written characters, including the characters, the writings, the literature and the historical narrations.

\footnotetext{
${ }^{56}$ Weber, Max. The Methodology of the Social Sciences. Trans. Han, Shuifa et al. Beijing: Central Compilation \& Translation Press, 1999. P. 60.
} 